\title{
Shaping of Competencies of Managers in Academic Incubators of Entrepreneurship in Poland
}

\author{
Joanna Kurowska-Pysz
}

Academy of Business in Dąbrowa Górnicza, Department of Management and Production Engineering of Academy of

Business in Dąbrowa Górnicza, Faculty in Cieszyn, ul. Frysztacka 44, 43-400, joanna.kp@gmail.com

Background and purpose: Participation of future entrepreneurs in Academic Incubators of Entrepreneurship (AIE) in Poland is one of the innovative paths to shape their managerial competences. The aim of the paper is to analyse and evaluate the activities of the AIEs as an environment inside of which managerial competencies are formed, and formulate recommendations concerning the improvement of AIEs, in terms of the development of managerial skills of future entrepreneurs.

Design/methodology/approach: The author relied on research - study surveys and empirical, qualitative, exploratory research, which were supported by figures. The author focused on four important issues:

- Motives of researchers and students interested in the support of AIE;

- The quality of support offered by the incubator to its participants as well as the frequency of use of this support by future entrepreneurs;

- The possibility of extending the support system for AIE participants;

- Traits / managerial and entrepreneurial competences desired in people running their own businesses.

Results: AlE participants are focused primarily on implementing their business ventures and to a much lesser extent, care about the simultaneous development of their managerial competencies to manage these projects. It is manifested, among other by differentiated assessment of the suitability of certain forms of support from the incubator and the low intensity of use of this support. Despite this, AIE participants perceive the development of desirable traits and strengthening of specific entrepreneurial, management competencies. It is not a very dynamic growth, although it translates into their motivation to start a business after leaving the incubator.

Conclusion: It is recommended to place greater emphasis on mobilizing the future entrepreneurs to make use of forms of support for the development of their managerial competences. It is necessary for complex preparation of future entrepreneurs to independently conduct business after leaving the incubator.

Keywords: Academic entrepreneurship, skills, manager, academic incubator of entrepreneurship

\section{Introduction}

With the changing economic relations, evolves the approach to tasks and managerial competences. Traditionally, the manager is defined as a person responsible for actions of subordinate structures, achieving business goals and striving to increase efficiency through the use of appropriate meth- ods of managing people, but it is difficult to determine what functions modern manager fulfills.

A modern manager should be a leader, an analyst and strategist, an inspirer, innovator and a good expert in his/ her industry. To distinguish the business roles of managers, they are also being divided into entrepreneurs - which are people setting up their own businesses and running them on

Received: $5^{\text {th }}$ September 2013; revised: $20^{\text {th }}$ October 2013; accepted: $22^{\text {th }}$ December 2013 
their own account and risk, and intrapreneurs - managers competent in managing the enterprise or part thereof, showing the ingenuity and initiative, but aimed at the development of the company which they do not own (Nogalski and Śniadecki, 2001).

The development of managerial competencies is an individual, multistage and complex process. Not everyone has the aptitude and ability to be a competent manager, but many skills associated with this function can be improved and developed with help of personal or general training. The effectiveness of developing managerial competencies depends on many factors, among others: individual predispositions, attitude towards personal development, type and quality of experience and the environment in which they are formed. Those managers who set up their own businesses are subject to specific verification by the market. Only some of them manage to get through the first, most difficult step associated with starting a business. The development of their own business model is usually a risky business, but also an excellent way to gain experience and competences, so useful in the course of work of managers. To meet the needs of people wishing to start their own business, Polish government has included in the Innovative Economy Operational Programme the measures for development of business incubators, which tasks include, among others, comprehensive support for young people starting businesses and testing their business ideas in operating at universities - Academic Incubators of Entrepreneurship. The activities of these units are focused primarily on the development of managerial skills of young people in developing their own businesses inside incubators, and also serving as organizational and even financial support in matters relating to accounting, marketing, administrative support, offices etc.

The priority actions of Academic Incubators of Entrepreneurship as a network to support budding entrepreneurship, especially in academia, is a comprehensive support of people who are planning to run independent business. The activity formula of this organization relies heavily on the institutional solution that enables its participants acquisition and handling of their own customers under the aegis of the Academic Incubators of Entrepreneurship, without having to set up their own business. The purpose of participation in an incubator to test and improve the participant's invented the business model so that after a period of 2-3 years of operation in the incubator, a mature start-up can smoothly become independent as a separate company. There is no doubt (Drucker, 2008) that entrepreneurship is a feature, as well as the behaviour of the entrepreneur and enterprises, i.e.

- willingness and ability to take up and solve new problems in a creative and innovative way,

- the ability to use new opportunities and occasions,

- flexibility to adapt to changing conditions.
Young manager may spend maximum two years in the Incubator. It is to be a period of intense personal and professional development, and above all gaining competencies enabling him further, self-development of company after leaving the incubator.

The aim of the paper is to determine the motivation of people joining the incubators and their awareness of the need to develop entrepreneurial traits and managerial competencies, as an essential requirement for success of business model being tested in an incubator. The author has also attempted to assess the extent to which participation in the incubator fosters the development of managerial skills of its participants. provides its participants with such support. The application purpose of this paper is to formulate recommendations for improving the system of support from AIEs for young managers developing their competencies in these units.

\section{Theoretical background}

The Recommendations of the European Parliament and of the Council on key competencies for lifelong learning from 10.11.2005, define the term "competence", as a combination of knowledge, skills and attitudes appropriate to the situation, especially in the labor market. The term: competences refers to specific individuals and their behaviours in the workplace i.e. desired behaviours, leading to competent actions. (Delamare Le Deist and Winterton, 2005). In this behavioural approach, specific behaviours within given competence are being described. In a general sense, they are defined as the ability of an employee to work for achieving the intended purpose, but in more specific terms - they mean whole knowledge, experience, attitudes and a willingness of employee to act in given circumstances, and the ability to adapt to changing conditions.

Managerial competencies include the perception of goals, attitudes and motives of individuals, knowledge of social structures (technological and social environment, organizational culture), and the effectiveness of reaching the objectives and social skills (communication, motivation, evaluation of team of employees, etc.) as well as the ability to apply knowledge in practice. Competencies are of fundamental importance for the awareness of managers, which is a special kind of perception of the company, in order to create ideas on changes and their implementation (Bartkowiak, 2003).

Leading role in the competences of managers plays professional knowledge (Kowalczyk \& Nogalski, 2007), skills of making the right decisions in time, interaction, experience, respect for cultural and ethical rules. Competence gap and negative effects of lack of competence are usually manifested in faulty management, unsatisfactory quality, loss of competitiveness, customers, and the market. Proper competencies management means the need of having and 
Table 1: Companies' and managers' competencies (Oleksyn, 2003).

\begin{tabular}{|l|l|l|}
\hline Competencies type & Reference to company & Reference to managers \\
\hline Universal & $\begin{array}{l}\text { - The ability to accomplish the mission, vision } \\
\text { and strategic objectives } \\
\text { - The ability to self-finance and income gen- } \\
\text { eration, } \\
\text { - Operating efficiency and ability to effective- } \\
\text { ly cooperate with the environment, } \\
\text { - The ability to conduct business with the } \\
\text { principles of law, ethics, and environmental } \\
\text { requirements. }\end{array}$ & $\begin{array}{l}\text { - The ability to design and effectively implement } \\
\text { the mission, vision and strategic objectives of } \\
\text { the company, } \\
\text { - Knowledge and professional skills to perform } \\
\text { all the functions of management and represent } \\
\text { the company externally, } \\
\text { - Efficient, rational and ethical management of all } \\
\text { the resources of the organization (human, finan- } \\
\text { cial, physical), } \\
\text { - Manage their time and information. }\end{array}$ \\
\hline Specific & $\begin{array}{l}\text { They arise from the portfolio of products, } \\
\text { markets, customers and determine the abil- } \\
\text { ity to manage the entity in variable market } \\
\text { conditions and the ability to apply solutions } \\
\text { adequate to the situation. }\end{array}$ & $\begin{array}{l}\text { They are a compilation of company-specific } \\
\text { competencies and professional skills of managers, } \\
\text { i.e. cognitive competencies (learning, comprehen- } \\
\text { sion, memory, curiosity, openness) and functional } \\
\text { competence (competence for a particular profes- } \\
\text { sion and work efficiently at a given position) (F. } \\
\text { Delamare Le Deist, J . Winterton, 2005). }\end{array}$ \\
\hline Personal & X & $\begin{array}{l}\text { Disclosed by the manager at work, as his } \\
\text { strengths enable him to effectively fulfil his role } \\
\text { as a professional such as creativity, communica- } \\
\text { tion skills, organizational skills, etc. }\end{array}$ \\
\hline
\end{tabular}

developing relevant competencies by both enterprise owners, as well as employed managers. Professionalization of the manager's work serves the utilization of his competencies in intelligently implemented work processes, and above all in the development of innovation. Increasingly important role among the components of managerial competencies plays creative thinking and action based on imagination, the ability to focus on clients, but also sensitivity to the problems of workers (Sajkiewicz, 2008).

It stands out among others the division on universal, specific and personal competencies (Oleksyn, 2003). First two categories may relate both to the company as well as its managers.

Managers should develop both universal and personal competencies, but also special ones correlated with company's specific market and industry situation. Particular emphasis on the development of competencies should be placed in the first period of manager's career when his powers and abilities are mainly based on theoretical, academic education, and to a lesser extent, on contact with professional practice. The AIEs support system offers young managers the ability to effectively connect these two spheres of gaining experience.

AIE network is mainly used by academic staff and students of Polish universities, interested in developing their own businesses. They have a very close contact with knowledge, since they combine scientific activities (academic staff) or education (students) with a perspective of thinking about their own company, which will be able to offer innovative products and services to the market. Within the AIE they have a chance to test their business models (Drucker, 2004). These provide an opportunity to experiment with their own business ideas without having to formalize a business venture. The support from the incubator also includes training, enabling the improvement of competencies of future entrepreneurs as managers of their own companies, as well as access to expertise that benefits business development. Nowadays knowledge is the most critical of all the resources that shape the company's activities, which forces companies to take a special care of not only the competence of managers, but also employees (Drucker, 1999). At the same time managers, supervisors, operators who require continuous learning from their subordinates, should be an example of development of their own knowledge and various skills. It is both knowledge the company has, as well as knowledge derived, for example, from a university, technology park, etc. When the ambition of being an entrepreneur, a manager is manifested by a researcher or student - his access to sources of knowledge is much better, but at the same time he has to face a number of specific barriers related with that environment (Szczepańska-Woszczyna \& Dacko-Pikiewicz, 2007).

As it is pointed out in the study of 51 micro-companies (start-ups) operating in the Slovenian technology parks, better knowledge management leads to better performance of young companies and greater satisfaction of 
their employees. Similar studies carried out in Austria have shown that start-ups operating in the incubators, created 1323 workplaces, while $72 \%$ of these have been formed by entrepreneurs with higher education, and it was directly connected with the creation of knowledge (Novak, Roblek and Devetak, 2013).

A favorable climate for close contact with knowledge for future managers is being provided by - among others their activity in Academic Incubators of Entrepreneurship, which model of functioning will be described later in this work. The Incubators can be seen as catalysts for the development of entrepreneurship, perceived as a process of creating new values, where as a result of time and effort, the risk incurred, the entrepreneur receives an award in the form of profit, satisfaction and independence (Hisrich and Brush, 1985). In this particular case, we can also talk about the socalled academic entrepreneurship, which, in accordance with the Polish Act of 27 July 2005 - Law on Higher Education (Journal of Laws No. 164, item. 1365, amended.) should be an important area of activity of universities. It is most commonly defined as a supporting of transfer of knowledge and new technologies into the economy, expressed, inter alia, by promoting pro-entrepreneurial attitudes among students and academic staff, as well as supporting entrepreneurs who are students, alumni, PhD students and researchers.

Academic entrepreneurship is currently being implemented in Poland, among others, through a network of 38 branches of Academic Enterprise Incubators that are working with leading Polish universities. These incubators are run by the foundation, which received funding from the Innovative Economy Program, a part of the European Regional Development Fund

(http://ec.europa.eu/regional_policy/thefunds/regional/ index_en.cfm). Incubators have been set up under the Project "Road to Entrepreneurial Polish," which aim was to create a new quality of supporting entrepreneurship in Poland, especially the small and medium-sized businesses created by scientists and students in academia (http://www.aip.org.pl/droga-do-polski-przedsiebiorczej). Incubators tend to focus on creating innovative business ideas which are supposed to give Polish economy a competitive advantage, and the improvement of competence of future entrepreneurs, managers, preparing them for running independent business in the future. The operational formula of Academic Incubators of Entrepreneurship provides innovative on a European scale, way of running a business in a modern pre-incubation program. By participating in the Incubator budding entrepreneur can legally operate on the market without having to register a company. In relations with the customer he is represented by the incubator, which issues invoices as a formal contractor of services provided by a young entrepreneur. In turn, the entrepreneur - incubator participant is employed on a civil law contract in the incubator and this way obtains payment for his business. This Polish solution differs substantially from the formula of academic incubators described in the literature (O'Shea et al., 2004). It should be noted that some form of incubation of start-ups are included in the activities of science parks. The International Association of Science Parks (IASP) defines it as an organization managed by specialized professionals, to promote a culture of innovation and development of all businesses and knowledge-based institutions. This is done through the creation and development of innovative companies in the process of incubation, with a strong focus on transfer of knowledge from science to business practice and through providing start-ups with a range of services to facilitate the functioning on the market in the first period of start-up activity (Marciniec, 2007). Similar considerations regarding comprehensive support of processes of incubation, start-ups, working in close connection with transfer of knowledge and know-how from academic environment to the economy relate to the British model (Hayward, 1993), Latvian and Spanish (www.innovation.lv/LTICA).

AIE participants, receive inter alia: legal and accounting services, the possibility to use modern office infrastructure, marketing, training and consultancy services, the possibility to exchange experience and apprenticeships with companies already operating in the incubator, and the opportunity to establish contacts with the business community and academia - called "networking". Businessman in an incubator uses the legal personality of the Foundation (VAT Identification Number, Business Registration No. REGON, Legal Register of Companies Certificate), thus avoiding the costs and risks of beginning business. In return a beginning businessman can focus on testing his business idea without a risk of error in the financial accounts. At the same time all the procedures of accounting services are designed so that the person operating in the Incubator is able to learn the standards and policies related with trade documents and the functioning of the company on the market. Any entrepreneur operating in the Incubator can build his business model and brand recognition at the same time. By participating in the program, he gains all the necessary tools for this purpose: ongoing marketing support, training (StarUpTraining program with the university and counseling tailored to the needs of the project - StartUp KickOf, Start Up Mentoring).

The most important in the operational formula of the Academic Enterprise Incubators is, that testing of business models is accompanied by continuous training of entrepreneurial and management competencies, both within the training system as well as individual support. The incubator is to be "a hotbed" of new ideas which requires the improvement of creativity and innovation of its participants. It is the ability to constantly seek novelty and their implementation that is now becoming one of the core competencies required of a modern manager, entrepreneur, but also from some employees. "Entrepreneur of knowledge" is a person actively seeking opportunities to manufacture and use knowledge to generate profits, such as transforming scientific knowl- 
edge, discoveries and inventions into new products, services and business technology (Jemielniak and Kozminski, 2012). Many authors have assigns the "spirit of enterprise" not only to business owners but also managers employed there as workers (Osborn and Słomczyński, 2005; Hisrich 1990, Cunningham and Lischeron 1991). Often, these workers are referred to as the so-called. knowledge workers representing a high level of expertise, training or experience, oriented to the creation, dissemination and practical application of knowledge (Davenport, 2007). Managerial competences acquired, among others, in Academic Incubators of Entrepreneurship, promote the development of innovation and creativity of both future business owners, as well as salaried managers. Own professional development of entrepreneurs as well as managers, supervisors and their subordinates understood as the management of careers can be a very effective strategy of personnel management, contributing to the success of the company (Suchar, 2003). Career management should take into account inter alia: appropriate training for achieving a high level of professional competence (Armstrong, 2000), which is required for both the entrepreneur - manager managing his own company, as well as a manager hired as an employee. In both cases, it is necessary to define career paths, correlated with the possibilities, aspirations and preferences of the manager, but also the structure of the company, its specificity and development plans. Such an entrepreneur-manager competence development formula is also offered by Academic Business Incubator, where business model testing is accompanied by improvement of managerial skills for future entrepreneurs. They need to gain the skills and experience to be able to creative activity, allowing for the initiation and development of the company, not just its observations, analysis and description of the activity (Timmons, 1990). Prospective entrepreneur should also possess the competencies to create or recognize opportunities and use them regardless of their current resources (Stevenson and Gumpert, 1992). The core competencies to support personal fulfillment, social inclusion, active citizenship and the possibility of the implementation of so-called self-programmable labor (Castills, 2003), can be considered (Bąk and Kulawczuk, 2009; Szczepańska-Woszczyna, 2004) as follows:

- communication in the mother tongue and in foreign languages,

- mathematical thinking and reasoning in terms of natural sciences,

- the ability to use a computer,

- ability to learn,

- social skills,

- entrepreneurship.

The activities of the company understood as a specific project in implementation consists of different stages and phases that require managers to specific competencies and skills. In terms of the conditions for introduction of the enterprise on the market, i.e. the first step of its operation the competencies and skills shall include: functional skills (finance, technology, marketing, business organization) and other such as: negotiation and orders contracting, project management, knowledge networking, responsibility and ability to make decisions, customer acquisition, business development, constructing of company structure and its protection (Fayolle, Kyro and Ulijn, 2005).

\section{Conceptual research framework}

The research problem of this paper concerns the process of shaping management skills of future entrepreneurs as a part of the activities of Academic Incubators of Entrepreneurship. It's all about a settlement on whether the current method of testing business models in Academic Incubators of Entrepreneurship is also effective for the development of managerial skills for future entrepreneurs. Using the findings of her own empirical research, the author seeks to determine to what degree the opportunity to develop entrepreneurial, managerial competencies affects faculty's and students' decision on joining the Academic Incubator of Entrepreneurship, and what actions should be taken by the incubators so that the process of development of these competencies was the most effective.

The cognitive aim of this paper is to analyze and evaluate the activities of the Academic Incubators of Entrepreneurship as an environment shaping managerial competence, and the application aim is to formulate recommendations for improving incubators' activity, in terms of the development of managerial skills of future entrepreneurs.

To achieve the research goal of this paper the author used study and empirical research - qualitative, exploratory, serving to better identify the problem and understand its essence. These studies were supported by the figures, obtained from 22 of the 31 young managers working in two branches of Academic Incubators of Entrepreneurship - in Bielsko-Biala and Katowice.

The author has focused on four important issues:

- Motives of researchers and students for their interest in the support of AIE,

- The quality of support offered by the incubator to its participants, among others, training, coaching, counselling and frequency of use of this support by future entrepreneurs

- Possibilities of extending the support system for AIE participants,

- Features / managerial and entrepreneurial competencies desired in people running their own businesses.

As a starting point for further scientific considerations three working hypotheses regarding the future behaviour of entrepreneurs using AIEs were raised: 
1. They focus primarily on opportunities to test their business model, without the risk of making a formal activity, while the possibility to develop entrepreneurial, managerial competencies is of secondary importance for them.

2. They do not use intensively enough of support, offered by the incubator.

3. They note the improvement of their managerial and entrepreneurial competencies in the course of cooperation with the incubator, which will translate into their motivation to start a business after leaving the incubator.

Working hypotheses listed above, were formulated based on the results of the report on the evaluation of effectiveness of the AIEs supported financially by the Ministry of Economy (2008) and from own observations of the author.

Despite the lack of generalizability of the study to the entire network of 38 AIEs, the results have an important cognitive meaning, inter alia, for institutions planning to disbursement of the next tranche of the Structural Funds for 2014-2020 - mainly in Silesia, where both studied incubators are located. It's about adjusting the shape of the EU support for the operating incubators to the real needs of their users, as well as further extension of the support and improvement of the quality of support provided by those incubators, including - in terms of placement - even greater emphasis on the development of managerial skills of young entrepreneurs operating in the incubators.

\section{Methodology}

Quantitative data used to verify the working hypotheses were obtained on the basis of an electronic survey questionnaire, which was sent to e-mail addresses of 31 young entrepreneurs operating in two branches of AIEs (in Katowice and Bielsko-Biala). Coordinators of incubators in BielskoBiala and Katowice were responsible for sending questionnaires to incubator participants, for which purpose they used their own database of e-mail addresses of persons operating in incubators. Due to the fact that participation in the study was voluntary and anonymous, there was no certainty of obtaining $100 \%$ of responses from persons to whom the questionnaire was addressed.

22 respondents answered the questionnaire. Despite efforts to broaden the scope of research, the Foundation which manages a network of AIEs has authorized only to conduct research in two branches (in Bielsko-Biala and Katowice). Due to the number of responses, the questionnaire was treated only as a numerical support for qualitative research because such small research sample should not be subjected to statistical treatment, due to the lack of representativeness for the assessment of the total population of entrepreneurs operating in this type of incubators. At the same time it is difficult to determine the real number of participants across the network of incubators as, for example, some people formally belonging to the incubator periodically suspend their cooperation or are simply not active.

The survey was divided into 8 questions open or closed, single or multiple choice. The first question served the assessment of the motives those interested in the support of AIEs are guided by. It was a multiple choice question. Respondents were offered 7 response options, including one open response.

In the second question, respondents were asked to assess the quality of each of the 13 forms of support offered by AIEs using the following scale: 1 - not meeting expectations, 2 at the level of expectations, 3 - above expectations. Another question also referred to forms of support offered by incubators, but this time respondents were to assess the frequency of using them on a scale: 1 - never, 2 - less than once a month, 3 - once a month, 4 - more than once a month .

The fourth question was an open one, and concerned indicating by the respondents these forms of support, which incubators do not provide, which could be useful for future entrepreneurs.

Fifth question referred to the evaluation of traits/competencies, useful for entrepreneurs running their own businesses (managing a company). Respondents were asked to assess each of the 18 proposed features on a scale: 1 - does not matter, 2 - less important, 3 - important, 4 - very important, 5 - key.

Further questions concerned the respondents already directly benefiting from the support of AIEs. In question 6, respondents referred to the same set of attributes/competencies as in question No. 5, assessing the extent to which they had them, prior entering the incubator and now. Evaluation was conducted on a scale: 1 - none, 2 - low rating, 3 - average rating, 4 - good rating, 5 - very good rating.

In question 7, respondents were asked to answer if, after exiting the incubator, they intend to start their own businesses. Five response options were provided, with one option open. The last question was used to assess whether respondents believe, activity in the Incubator is an appropriate form of development of their managerial competencies as future entrepreneur.

Before the survey, the test survey was performed, which involved three participants of AIE in Bielsko-Biala. The results of the test survey helped to clarify some variants of answers and verify the order of questions.

Among 22 respondents to the questionnaire 18 of them were people with higher education and 4 persons with secondary education. As many as 15 respondents had been working in the incubator for less than 6 months, 1 person for about a year, three more people had been working for more than one year, and 3 people - more than two years. 4 persons participating in the study had student status, and the 18 - a graduate.

All returned surveys were complete. After calculating the results obtained for individual answer variations to ques- 
tions No. 1-8, data were subjected to statistical processing in MS Excel (calculation of the arithmetic mean), which allowed the author to obtain the results presented in Table 2 . As mentioned above, the resulting figures are not representative to the whole population of incubator participants, but they have only supporting character in relation to qualitative, exploratory research conducted by the author.

\section{Results}

The first working hypothesis included a statement that future entrepreneurs benefiting from AIEs focus primarily on opportunities to test their business model, without risk of making a formal business activity, while development of their entrepreneurial, managerial competencies is of secondary importance for them.

Table 2 presents the motivation of respondents to test their business ideas in the incubator.

Due to the fact that the question was a multiple choice one, the answers do not add up to 22. It follows that more than half of the respondents decided to cooperate with the incubator due to the prestige and image, this form of enterprise development support enjoys, nearly half of them as an argument for its participation in the incubator also stated the desire to reduce the risk of testing a business idea prior to

Table 2: Motives leaning respondents to test their business idea in the incubator.

\begin{tabular}{|l|l|c|}
\hline No. & Variant of response & Number of responses \\
\hline 1. & Confidence in the principles of the AIE, its prestige and good image & 13 \\
\hline 2. & $\begin{array}{l}\text { The desire to reduce the risk of testing a business idea before a formal foundation } \\
\text { of business (work in civil-law contract) }\end{array}$ & \multirow{2}{*}{4} \\
\hline 3. & $\begin{array}{l}\text { The desire to develop their management skills prior to the formal foundation of } \\
\text { the company (training, counseling, legal assistance, etc.) }\end{array}$ & 0 \\
\hline 4. & $\begin{array}{l}\text { The desire to meet other enterprising people, the opportunity to establish business } \\
\text { contacts }\end{array}$ & 2 \\
\hline 5. & $\begin{array}{l}\text { Convenience of the activity within AIE, such as availability, form of settlement, } \\
\text { lower cost of activity, etc. }\end{array}$ & 1 \\
\hline 6. & Versatile support for those operating in the AIE. & 0 \\
\hline 7. & Other & \\
\hline
\end{tabular}

Table 3: The assessment of the quality of support provided by the incubator.

\begin{tabular}{|l|l|c|c|}
\hline No. & Rated type of support & Average rating & Standard deviation \\
\hline 1. & AIE Director's counselling regarding running a business & 2,00 & 0,67 \\
\hline 2. & Legal care, for example, provided legal advices & 1,68 & 0,56 \\
\hline 3. & Provision of accounting services in the field of HR and payroll & 2,00 & 0,80 \\
\hline 4. & The right to use the logo Academic Incubators of Entrepreneurship & 1,95 & 0,71 \\
\hline 5. & The use of AIE's offices, meeting rooms and office equipment & 2,18 & 0,78 \\
\hline 6. & $\begin{array}{l}\text { The assistance in obtaining contracts - organization of business meet- } \\
\text { ings }\end{array}$ & 1,77 & 0,73 \\
\hline 7. & Promotion of business activity of AIE participant during organized events & 1,90 & 0,93 \\
\hline 8. & Individual bank sub-account & 1,95 & 0,77 \\
\hline 9. & Availability of applications supporting business processes & 1,77 & 0,67 \\
\hline 10. & Availability of specialized training in marketing and promotion & 2,00 & 0,67 \\
\hline 11. & Availability of specialized training in entrepreneurship & 2,09 & 0,51 \\
\hline 12. & $\begin{array}{l}\text { Coaching from the AIE regarding the development of participant's busi- } \\
\text { ness idea }\end{array}$ & 2,00 & 0,73 \\
\hline 13. & Support in obtaining funds to start a business & 1,54 & 0,58 \\
\hline
\end{tabular}


the formal foundation of the company. Only four respondents indicated a desire to develop their management skills in an incubator prior to the formal foundation of business. The results presented in Table 1, confirm the hypothesis 1 put forward by the author that the wish to develop entrepreneurial, management competencies within the incubator, is of secondary importance to the participants of AIE, compared to other motives which prompt them to enter into the incubator.

Another question concerned the assessment of the quality of support provided by the incubator (Table 3).

The result of this question is a rating, calculated as an arithmetic average of 22 responses. Respondents had the following grading scale at their disposal: 1 - do not meet my expectations, 2 - at the level of my expectations, 3 - above my expectations. Table 3 also shows the standard deviation in the evaluation of individual forms of support.

When it comes to the quality of support from the incubator, the respondents rated highest overall infrastructure of offices and meeting rooms (2.18) and the availability of specialized training in entrepreneurship (2.09) and consulting business, coaching for the development of business ideas, the availability of training specialized in marketing and promotion, and the quality of accounting services in the field of HR and payroll (after 2.0). This means that in spite of the opportunity to develop their entrepreneurial, managerial competencies in the incubator being of secondary importance for future entrepreneurs, they highly appreciated these forms of support that offer them that opportunity.

The second working hypothesis assumed that future entrepreneurs do not use the support of the AIEs intensely enough. The frequency of use of particular forms of support for the incubator participants are presented in Table 4.

In relation to particular types of support provided by the incubators varying frequency of use by the participants has been observed. A relatively large group of AIE participants avoids the use of specialized training in marketing, promotion, entrepreneurship and AIE in the development of a business idea. The frequency of use of these forms of support by other AIE participants is also not very high.

The analysis of the results presented in Table 3 confirms the hypothesis 2 - that the participants of incubators do not use intensively enough the offered support. This is evidenced by the relatively high number of respondents choosing the options "never" or "less than once a month." At the same time it is worth noting that even these forms of support (Table 2), which enjoyed a relatively high reputation among the respondents (score of at least 2.0), i.e. "Availability of specialized training in entrepreneurship", "AIE Director's counselling regarding running a business", "Coaching from the AIE regarding the development of participant's business idea", the "Availability of specialized training in marketing

Table 4: The frequency of using the services of the incubator.

\begin{tabular}{|l|l|c|c|c|c|}
\hline \multirow{2}{*}{ No. } & Rated type of support & \multicolumn{3}{|c|}{$\begin{array}{c}\text { The frequency of use of particular forms of } \\
\text { support / number of responses }\end{array}$} \\
\cline { 3 - 5 } & & Never & $\begin{array}{c}\text { Less than } \\
\text { once a } \\
\text { month }\end{array}$ & $\begin{array}{c}\text { Once a } \\
\text { month }\end{array}$ & $\begin{array}{c}\text { More than } \\
\text { once a } \\
\text { month }\end{array}$ \\
\hline 1. & AIE Director's counselling regarding running a business & 6 & 7 & 8 & 1 \\
\hline 2. & Legal care, for example, provided legal advices & 5 & 9 & 3 & 5 \\
\hline 3. & Provision of accounting services in the field of HR and payroll & 1 & 9 & 5 & 7 \\
\hline 4. & Using the logo of Academic Incubators of Entrepreneurship & 7 & 6 & 4 & 5 \\
\hline 5. & Use of AIE's offices, meeting rooms and office equipment & 4 & 7 & 6 & 5 \\
\hline 6. & $\begin{array}{l}\text { The assistance in obtaining contracts - organization of busi- } \\
\text { ness meetings }\end{array}$ & 7 & 11 & 3 & 1 \\
\hline 7. & $\begin{array}{l}\text { Promotion of business activity of AIE participant during orga- } \\
\text { nized events }\end{array}$ & 8 & 10 & 3 & 1 \\
\hline 8. & Individual bank sub-account & 0 & 7 & 4 & 11 \\
\hline 9. & Use of applications supporting business processes & 6 & 7 & 6 & 3 \\
\hline 10. & Use of specialized training in marketing and promotion & 5 & 9 & 6 & 2 \\
\hline 11. & Use of specialized training in entrepreneurship & 6 & 5 & 5 & 6 \\
\hline 12. & $\begin{array}{l}\text { Use of coaching from the AIE regarding the development of } \\
\text { participant's business idea }\end{array}$ & 8 & 5 & 3 & 6 \\
\hline 13. & Use of support in obtaining funds to start a business & 10 & 4 & 4 & 4 \\
\hline
\end{tabular}


and promotion", and the "Provision of accounting services in the field of HR and payroll" - are not the most commonly used forms of support.

The third working hypothesis assumed that future entrepreneurs observe an improvement in their managerial competencies in the course of cooperation with the incubator, which will translate into their motivation to start a business after leaving the incubator.

In the last part of the survey, respondents assessed, among others: the importance of stated traits/competencies for entrepreneurs starting their own business. Then, the respondents evaluated their own traits / management competencies at the moment of joining the incubator and at the time of the study (Table 5).

In question 4 (results given in Table 5) the respondents had access to a rating scale: 1 - does not matter, 2 - of little importance, 3 - important, 4 - very important, 5 - key. As shown in Table 5 for incubators participants consider the following features important or crucial to people start- ing their own business: self-motivation, positive personal image, skills: problem solving, stress management and time management as well as innovation and both enthusiasm and determination in achieving a goal. These attributes were indicated by 15 participants of the study.

In turn, Table 6 shows the own-evaluation of respondents, in relation to the attributes/competencies desired for entrepreneurs. Respondents were asked to assess these attributes for the period prior to their activity in the incubator and during their activity in the incubator. In both cases, the respondents had access to a rating scale: 1 - none, 2 - low rating, 3 - average rating, 4 - good rating, 5 - very good rating. The results were obtained as an arithmetic mean of the 22 responses. According to survey results analysis, the use of the incubator dramatically improved competencies of respondents in terms of: self-motivation to work, problem-solving and time management skills, motivation to share their knowledge with others, as well as the level of acceptance of risk in business, expertise in a particular

Table 5: The significance of attributes / competencies for entrepreneurs starting their own businesses.

\begin{tabular}{|c|c|c|c|c|c|c|}
\hline \multirow[b]{2}{*}{ No. } & \multirow[b]{2}{*}{ Attributes/competencies } & \multicolumn{5}{|c|}{ Evaluation option/number of indications } \\
\hline & & No matter & $\begin{array}{l}\text { Not very } \\
\text { important }\end{array}$ & Important & $\begin{array}{c}\text { Very } \\
\text { important }\end{array}$ & Key \\
\hline 1. & Ability to work in a group & 1 & 2 & 10 & 7 & 2 \\
\hline 2. & Communication, ease of establishing contacts & 0 & 1 & 6 & 4 & 10 \\
\hline 3. & Self-motivation to work & 0 & 2 & 4 & 5 & 11 \\
\hline 4. & Self-presentation, personal image & 0 & 1 & 5 & 10 & 6 \\
\hline 5. & Ability to solve problems & 0 & 2 & 4 & 10 & 6 \\
\hline 6. & Ability to cope with stress & 0 & 2 & 6 & 8 & 7 \\
\hline 7. & Ability to manage time, work planning & 0 & 1 & 6 & 10 & 5 \\
\hline 8. & $\begin{array}{l}\text { Self-improvement, willingness to learn } \\
\text { throughout life }\end{array}$ & 0 & 3 & 7 & 6 & 6 \\
\hline 9. & The ability to share knowledge with others & 0 & 3 & 13 & 6 & 0 \\
\hline 10. & Innovation, openness, willingness to change & 0 & 0 & 7 & 7 & 8 \\
\hline 11. & $\begin{array}{l}\text { The enthusiasm and determination in achiev- } \\
\text { ing a goal }\end{array}$ & 0 & 3 & 4 & 7 & 8 \\
\hline 12. & Independence & 0 & 2 & 7 & 7 & 6 \\
\hline 13. & Controlling of own work and work of others & 0 & 3 & 8 & 6 & 5 \\
\hline 14. & Acceptance of risk in business & 0 & 2 & 7 & 9 & 4 \\
\hline 15. & Ability to learn from the experiences of others & 0 & 3 & 5 & 12 & 2 \\
\hline 16. & Ability to formulate business strategies & 0 & 1 & 7 & 10 & 4 \\
\hline 17. & Level of expertise in your industry & 0 & 2 & 7 & 8 & 5 \\
\hline 18. & $\begin{array}{l}\text { he level of knowledge about your market, } \\
\text { competitors, customers }\end{array}$ & 0 & 1 & 7 & 8 & 6 \\
\hline 19 & The ability to exploit the opportunities & 0 & 3 & 5 & 7 & 6 \\
\hline
\end{tabular}


Table 6: Self-assessment of respondents in relation to selected attributes/competencies

\begin{tabular}{|c|c|c|c|}
\hline \multirow[b]{2}{*}{ No. } & \multirow[b]{2}{*}{ Attributes/competencies } & \multicolumn{2}{|c|}{ Average rating } \\
\hline & & $\begin{array}{l}\text { Self-assessment - } \\
\text { prior to activity in the } \\
\text { AIE }\end{array}$ & $\begin{array}{l}\text { Self-assessment at the } \\
\text { time of audit }\end{array}$ \\
\hline 1. & Ability to work in a group & 3,54 & 3,72 \\
\hline 2. & Communication, ease of establishing contacts & 3,77 & 4,04 \\
\hline 3. & Self-motivation to work & 3,22 & 3,72 \\
\hline 4. & Self-presentation, personal image & 3,54 & 3,63 \\
\hline 5. & Ability to solve problems & 3,36 & 4,04 \\
\hline 6. & Ability to cope with stress & 3,63 & 4,04 \\
\hline 7. & Ability to manage time, work planning & 3,45 & 4,04 \\
\hline 8. & Self-improvement, willingness to learn throughout life & 3,31 & 4,18 \\
\hline 9. & The ability to share knowledge with others & 3,22 & 3,86 \\
\hline 10. & Innovation, openness, willingness to change & 3,40 & 4,22 \\
\hline 11. & The enthusiasm and determination in achieving a goal & 3,50 & 3,90 \\
\hline 12. & Independence & 3,63 & 4,04 \\
\hline 13. & Controlling of own work and work of others & 3,31 & 3,90 \\
\hline 14. & Acceptance of risk in business & 3,50 & 4,04 \\
\hline 15. & Ability to learn from the experiences of others & 3,09 & 4,22 \\
\hline 16. & Ability to formulate business strategies & 3,09 & 3,90 \\
\hline 17. & Level of expertise in your industry & 3,54 & 4,22 \\
\hline 18. & $\begin{array}{l}\text { The level of knowledge about your market, competitors, cus- } \\
\text { tomers }\end{array}$ & 3,45 & 4,04 \\
\hline 19 & The ability to exploit the opportunities & 3,27 & 4,04 \\
\hline
\end{tabular}

industry and knowledge of the market, competitors and customers (an increase of average assessment by at least $0.50)$. Strongly strengthened were their skills in three areas: the formulation of business strategies, innovation, motivation for lifelong learning, and the ability to learn from the experiences of others, as well as the formulation of business strategies and exploit the opportunities (an increase of average assessment by at least 0.75 ). The following skills were rated the lowest by the respondents before entering the incubator: the ability to learn from the experiences of others and the ability to formulate business strategies (average score 3.09), as well as self-motivation to work and the ability to share knowledge with others (average score 3.22), while none of the proposed attributes/competencies have been assessed at a level of at least 4.0. Currently, a number of attributes which the average rating is above 4.0 has been identified among the respondents, which the respondents considered earlier as crucial for people who want to start their own business. These are: problem solving, coping with stress and time management as well as innovation, which, together with a high level of industry expertise, were rated the highest (4.22 both).

Working hypothesis No. 3 put forward by the author assumed that respondents note the improvement of their management and entrepreneurial competencies during their cooperation with the incubator, which should translate into their motivation to start a business after leaving the incubator. This thesis proved to be true in part because the 10 respondents said that at the end of their activity in the business incubator they are going to open their own business, since they are properly disposed. Another five people claim that they will decide to open up the company if they get additional experience outside the incubator, while seven people had no opinion on the matter. None of the respondents said that after leaving the incubator they will not start a company. In addition, 15 respondents stated that in their opinion the activities at the Academic Incubator of Entrepreneurship is an appropriate form of developing management competencies for a future entrepreneur, while seven respondents had no opinion on the matter. No one denied the thesis that the Academic Incubators of Entrepreneurship are an appropri- 
ate form to develop management competencies for future entrepreneurs.

\section{Discussion}

It is impossible to acquire such entrepreneur, manager skills without education and gaining experience, without learning on real examples. For this reason, the use of the incubator should be considered highly beneficial for future entrepreneurs. Regardless of creating the conditions for testing business ideas, the role of each incubator should be shaping and systematic development of the competencies of its participants. Meanwhile, according to studies, confirming working hypothesis No. 1 put forward by the author, those wishing to take advantage of the incubator rarely expect this kind of support. Incubator participants are focused primarily on how to best prepare their businesses from the organizational and market point of view, not noticing how large a role in the effective implementation of business play the skills of an entrepreneur. Personal experience of the author in collaboration with incubators confirms, that the person entering the incubator often in the course of their activities change or modify the concepts of future business, and gained experience, qualifications and skills are somewhat universal - they will be useful in many areas of future activity. As it turns out, it is most difficult to convince participants of the incubator to use such support (results shown in Table No. 3). When it comes to advice on business, participation in specialized training on entrepreneurship, promotion and marketing or use of the assistance of a coach supporting the development of business ideas - great part incubator participants does not use such support at all, and many use them only occasionally, less than once a month. This is despite the fact that incubators are offering them a diverse and professional offer in this area, which is assessed as being consistent with the expectations of incubator participants, which is confirmed by the results of evaluation of the quality of support provided in Table No. 3.

These reflections prompt the Author to recommend the network of Academic Incubators of Entrepreneurship to put more emphasis on improving the participants' awareness of the need to develop their entrepreneurial and managerial skills through the use of the multiple forms of support in this field. It is also important, due to the fact that Academic Incubators of Entrepreneurship are co-financed by the European Regional Development Fund, thus it is all about the effective spending of EU funds. It is in the interest of all parties that people who leave the incubator were best prepared for the role of the entrepreneur, manager, also because the target group, i.e. incubator academic staff and students, need special support in this regard. Therefore, on the one hand, it is necessary to recommend the incubator participants to use more of such forms of support, and also the continuous enrichment by the incubators of their offer of courses, training, and individual work with participants, focused on improving their managerial and entrepreneurial skills. Confirmation of working hypothesis No. 2 put forward by the author, leads to the conclusion that perhaps one should consider imposing an obligation to use forms of support for the development of competencies on the incubator participants. This can be somewhat restrictive, but may also contribute to a greater interest in this type of services provided by the incubator. On the other hand, the incubators should consider the specific profile of courses, trainings, etc. that would be mandatory for participants, but also precisely tailored to the needs of the incubators' target group, i.e. academic staff and students.

Another issue is the assessment of the effects of participation in an incubator when it comes to development of the selected features and improving the entrepreneurial competencies of people using such support. As part of the study the author was able to sketch an image of professional entrepreneur who is starting a business, which according to the respondents should be characterized by, among others: communicativeness and the ability to make contacts easily, and also possess the auto-motivation to work. The following also distinguish themselves among other attributes and competencies mentioned by the respondents: innovation, openness and willingness to change the enthusiasm and determination to achieve a goal. Without a doubt, a certain level of these traits and skills can be attributed to persons acting in an incubator, as indicated by the very fact that they decided to join the incubator. These were 7 people among the nearly 8-thousand community of the University of Bielsko-Biala, while among the nearly 40-thousand community of the University of Silesia - 25 people. A separate discussion is required to answer a question, why such a small number of people in the academic community is interested in the activity inside Academic Incubators of Entrepreneurship? Is it influenced by a still-dominant academic career model which is still based mainly on education and conducting basic research? Why only a modest representation of students decides to start a business in this formula during the study, although the principle of incubator's activity in relation to them is the proximity to place of study and earning? The author's intention is to conduct further study of the activities of the Academic Incubators of Entrepreneurship in order to find an answer to these issues, while in this study the author has focused on the analysis of the evaluation of development of entrepreneurial management skills, by the respondents. Due to the relatively short duration of operation of the network of Academic Incubators of Entrepreneurship (2 to 3 years for each branch) it was difficult to find enough examples of continuation of business activity by the startups in order to verify on this basis, whether the current method of testing business models in Academic Incubators of Entrepreneurship is also effective for the development of managerial skills for future entrepreneurs. The author 
therefore asked people currently participating in incubators to assess their own competence development.

Working hypothesis 3 put forward in this paper assumed that participants notice the improvement of their managerial and entrepreneurial skills during their cooperation with the incubator, which is reflected in their motivation to start a business after leaving the incubator. The evaluation results presented in Table 6 confirms that the respondents see the development of desirable traits and strengthening of particular entrepreneurial, managerial skills, but one has to note that this increase is not very dynamic. Respondents state that at the time of entry into the incubator they had the vast majority of mentioned traits and competencies on at least average level (score of at least 3.0). As a result of participation in an incubator a distinct increase of some of the attributes and competencies has been noted (e.g. by 0.75 percentage assessment points), while for many others the increase is lesser (e.g., about 0.25 percentage point evaluation). Of course, it is difficult to assume that all of participants' traits/managerial, entrepreneurial competencies will be developed in a harmonious way, as a result of participation in training courses, training or coaching, as it depends to some extent on personal qualities, as well as e.g. frequency and motivation to use the support of the incubator. Nevertheless, we should consider which of the traits/ competencies the incubators should particularly take into account when it comes to a matter of training, and other forms of support for the participants. The potential of persons acting in incubators should be kept in mind, primarily related to the transfer of knowledge, as a product, to the market, that one can make profit on, such as: scholars that provide their expertise as individual entrepreneurs, such as consulting, R \& D services, etc. Without a doubt developed qualities and skills should facilitate the establishment of science-business cooperation and eliminate many barriers on the side of academic staff and students, which can be seeing this field (Kurowska-Pysz, 2012).

The author tried to obtain comparable results of studies regarding competencies of people setting up their business in AIE, but it turned out that such research has not yet been carried out. To my knowledge, the only similar study concerning competencies of people setting up a start-up and enjoying the support of European Social Fund was carried out in the framework of the project »Give yourself a chance - hire yourself", carried out by Polish Foundation for Supporting Economic Development "OIC Poland " in Lublin (Ćwik, Zbroja and Armour, 2013). The study involved 60 people who were starting a business, using the process of incubation with comprehensive support including, among others: counselling (individual, competence, motivation and business), training the development of business plans as well as business and financial support.

Measurement of competencies of people who want to self-employ themselves was made using ASTRA STARTER tool, which consists of the following scales:
1. Personal strengths,

2. Dealing with difficulties,

3. Prudence,

4. Self-trust,

5. Knowledge of legal and business environment,

6. Financial management,

7. Starting up a business,

8. Understanding the impact of economic factors.

First four scales relate to general competencies, four more to competencies specific for making business. The results mentioned studies show that obtaining financial support for running their own business, and minimizing the risk of business failure due to so-called bridging financial support in the first year of operation (covering rent fees, accounting services, social insurance contributions, etc.), were of paramount importance to the participants of this project (somewhat more favourable conditions for starting a business than in AIEs case), while comprehensive consulting and training which they could use, were of secondary importance to them, and were treated by Project participants as a compulsory requirement to obtain financial support for the development of their own business. These studies also confirmed that, as a result of the project, people who finally managed to start a business obtained significantly higher level of competencies described in the 8 scales above, while those who did not receive support for this purpose (e.g., due to poor motivation, not good enough business idea, etc.) had an average or lower level of competencies. In case of this study, however, the author failed to perform comparative evaluation of the quality of support for incubated companies, because cited study and research done by the author related to the projects implemented by different guidelines, which is also reflected in the range of support received by incubated companies in both cases.

\section{Conclusions}

The operational aim of all business incubation programs is to create the best possible conditions for people who want to develop their own business. AIEs are primarily focused on the support of people associated with academia, i.e. academic staff and students, who - in their companies - bet on transfer of knowledge and its application in the economy. The vast majority of incubation programs in Poland is supported by the European Union within the framework of various projects. It is similar in AIEs case, which function as an EU project that requires a specific formulation of execution and settlement. This strongly limits the flexibility of incubators, as there is not even possible to change the profile of support for participants beyond what is included in the budget of the Project. This is probably one of the reasons why people who are managing incubators are mainly focused on reaching the quantitative indicators of the pro- 
ject, such as the number of companies established in the incubator, but qualitative indicators - such as the quality of the preparation of future entrepreneurs to business activities - that are difficult to measure on the project level, are far less important. For this reason, the study made by the author should be a valuable pictorial material for the management of incubators and people planning EU support for incubators EU for 2014-2020. The study confirms that entrepreneurs using incubators, perceive their business career as primarily one specific project that they want to do in cooperation with the incubator. They do not attach sufficient weight to the fact that at that time, competencies and managerial skills that are gained by them, will pay dividends throughout their lives, regardless of their future professional positions, and regardless of whether the business model created by them in the incubator, will be sustainable and profitable. As it is shown by the research, businesses men leaving the AIE as a mature start-up have a proven idea for their own business in hand, but they are not fully prepared for running it, from the point of view of managers' and entrepreneurs' competencies. It is caused by incubators' activity formula (no compulsion to use certain forms of support), and also low interest from the participants of the incubator. In such a situation it is necessary to take action to motivate future entrepreneurs to intensify the use of the incubator.

Obtained study results are not representative for the entire network of Academic Incubators of Entrepreneurship, due to the fact that it included only two branches of the AIE network. This, however, was a result of a decision of a Foundation which is managing he incubators, which agreed only on the study of such a small range. Nevertheless, the author intends to present her findings to the AIE network with a recommendation regarding the need to create an attributes/competencies profile that should be developed from the point of view of the target group of incubator participants. Without a doubt, current system of support is beneficial for strengthening these qualities/competencies, as evidenced by numerous statements concerning the readiness of respondents to run a business after leaving the incubator, but it appears that further efforts are required in this regard. The idea is to build a profile of traits/competencies that should be reinforced in people participating in the incubators, in order to enable them to become effective managers in the future (Drucker, P., 1994), regardless of whether they develop their careers as independent entrepreneurs or as salaried managers. The author treats this task as a next stage of research on the managerial competencies of AIE participants in 2014-2020.

\section{Literature}

Aernoudt, R. (2004). Incubators: Tool for Entrepreneurship? Small Business Economics, 23 (2), 127-135, http://dx/doi. org/10.1023/B:SBEJ.0000027665.54173.23
Armstrong, M. (1998). Managing People. A Practical Guide for Line Managers. London: Kogan Page Ltd.

Bartkowiak, G. (2003). Skuteczny kierownik-model i jego empiryczna weryfikacja [An effective manager - model and its empirical verification]. Poznań: Wydawnictwo Akademii Ekonomicznej.

Bąk, M. \& Kulawczuk, P. (2009). Warunki skutecznej wspótpracy pomiędzy nauka a przedsiębiorstwami [Conditions for effective cooperation between science and industry]. Warsaw: Instytut Badań nad Demokracją i Przedsiębiorstwem Prywatnym.

Cunningham, J.B. \& Lischeron, J. (1991). Defining entrepreneurship. Journal of Small Business Management, 29 (1), 49-61.

Ćwik, K. \& Zbroja, A. (2013). Kompetencje osób rozpoczynających działalność gospodarczą w województwie lubelskim na przykładzie działania 6.2 Programu Operacyjnego Kapitał Ludzki [Competence of persons beginning the business activity on the example of measure 6.2 Support and promotion of entrepreneurship and self-employment of the Operational Programme Human Capital of Lubelskie Voivodeship]. Zeszyty Naukowe WSEI, seria: EKONOMIA, 6(1/2013), p.p. $125-153$.

Davenport, T.H. (2005). Thinking for living. How to get better performance and results from knowledge workers. Boston: Harvard Business School Publishing.

Delamare Le Deist F. \& Winterton, J. (2005). What is competence, Human Resourse Development International, 8(1), 27-46, http://dx.doi.org/10.1080/1367886042000338227

Drucker, P.F. (2006). The Effective Executive. The definitive guide to getting the right thinks done, New York: Harper Business Publishers.

Drucker, P.F. (1994). Post-Capitalist Society. New York: HarperBusiness Publishers.

Drucker, P.F. (2004), The Daily Drucker. New York: HarperBusiness Publishers.

Drucker, P.F. (2008). The Essential Drucker. New York: HarperBusiness Publishers.

Fayolle, A., Kyro, P. \& Ulijn, J. (2005). Entrepreneurship Research in Europe. Outcomes and Perspectives. Northampton: Edward Elgar Publishing Inc.

Hayward, G. (1993). UK Science Park Association - Science Park Directory, 5th ed., Technovation, 13 (7), 477-478, http:// dx.doi.org/10.1016/0166-4972(93)90034-S

Hisrich, R.D. (1990). Entrepreneurship/intrapreneurship, American Psychologist, 45(2), 209-222, http://psycnet.apa. org/doi/10.1037/0003-066X.45.2.209

Hisrich, R.D. \& Brush, C.G. (1985). The Woman Entrepreneur: Characteristic and Prescriptions for Success. Lexington: Lexington Books.

Jemielniak, D. \& Koźmiński A.K. (2012). Zarządzanie wiedza [Knowledge Management]. Warsaw: Oficyna a Wolters Kluwer business.

Kowalczyk, A. \& Nogalski, B. (2007). Zarządzanie wiedza [Knowledge Management]. Warsaw: Diffin.

Kurowska-Pysz, J. (2012). Miejsce wiedzy w rozwoju innowacyjnych firm - szanse i bariery wspótpracy ośrodków akademickich i przedsiębiorstw / Studia ekonomiczne regionu łódzkiego - formy i uwarunkowania wspótpracy we wspótczesnej gospodarce [Place of knowledge in the development of innovative companies - opportunities and barriers in cooperation between universities and enterprises / Economic studies of 
Lodz region - the forms and conditions of cooperation in the modern economy]. Łódź: PTE Oddział w Łodzi.

Nogalski, B. \& Śniadecki, J. (2001). Umiejętności menedżerskie w zarzadzaniu przedsiębiorstwem [Managerial skills in business management]. Bydgoszcz: Oficyna Wydawnicza Ośrodka Postępu Innowacyjnego.

Novak, R., Roblek, M. \& Devetak, G. (2013). Relation between Knowledge Management and Turnover in Slovenian Micro and Small Start-Up Organisations. Organizacija, 46(3), 99-107, http://dx.doi.org/10.2478/orga-2013-0008.

Marciniec, B. (2007). Rola parków naukowo-technologicznych $w$ rozwoju matych $i$ średnich przedsiębiorstw [The role of science and technology parks in the development of small and medium-sized enterprises], Poznań: Wydawnictwo Poznańskie.

Oleksyn, T. (2006). Zarządzanie kompetencjami. Teoria i praktyka [Competence management. Theory and practice], Cracow: Oficyna Wydawnicza.

Osborn, E. \& Słomczyński, K.M. (2005). Open for business. The persistent entrepreneurial class in Poland, Warsaw: IFiS Publishers.

O'Shea, R.P., Allen, T.J., Chevalier, A. \& Roche F. (2005). The Creation of Spin-off Firms at Public Research Institutions: Managerial and Policy Implications. Research Policy, 34 (7), 994-1009, http://dx.doi.org/10.1016/j.respol.2005.05.011

Public Profits Sp. z o.o. w Poznaniu (2008). Raport z badania ewaluacyjnego: Ewaluacja działalności Akademickich Inkubatorow Przedsiębiorczości (AIP) wspartych finansowo ze środków Ministerstwa Gospodarki [Report of the evaluation: Evaluation of the activities of the Academic Incubators of Entrepreneurship financially supported by the
Ministry of Economy], Warsaw: Ministerstwo Gospodarki Rzeczpospolitej Polskiej.

Stevenson, H.H. \& Gumpert, D.E. (1992). The Entrepreneurial Venture, Boston: Harvard Business School Publications.

Sajkiewicz, A. (2008). Kompetencje menedżerów w organizacji uczącej się [The competence of managers in a learning organization]. Warsaw: Difin.

Suchar, M. (2003). Kariera i rozwój zawodowy [Career and professional development], Gdańsk: Ośrodek Doradztwa i Doskonalenia Kadr.

Timmons, J. (1990). New Venture Creation, Boston: IRVIN.

Szczepańska-Woszczyna K. (2004). Challenges of the labour market for knowledge, skills and attitude of managers-to-be. In: Formation et developpement des competences manageriales dans l'Europe elargie, Mikołajczyk Z. \& Martin C. (eds.). Łódź University of Łodz.

Szczepańska-Woszczyna K. \& Dacko-Pikiewicz Z. (2007). Attitudes of graduates towards the education and the career. In: Economic studies - whether only a knowledge and abilities, Łódź: FEP.

Joanna Kurowska-Pysz is an assistant professor in the Department of Management and Production Engineering of Academy of Business in Dabrowa Gornicza. She is working with companies and local government, especially in the field of consulting and obtaining EU funds. She has a large experience in managing projects related to the development of academic entrepreneurship, inter alia in the academic centre for technology transfer and academic incubator of entrepreneurship. Among the dozens of published its work, nearly 20 applies to science-business collaboration and innovation and academic entrepreneurship. 